\title{
A STUDY ON DYSPHAGIA DUE TO BENIGN OESOPHAGEAL STRICTURES
}

\author{
Krishna Gopal Sharma ${ }^{1}$,Minaxi Sharma ${ }^{2}$ Deepak Sethi ${ }^{3}$, Rajveer Singh ${ }^{4}$, Anjali Sethi $^{5}$ \\ ${ }^{1}$ Assistant Professor, Department of Surgery, Rabindranath Tagore Medical College, Udaipur, Rajasthan. \\ ${ }^{2}$ Assistant Professor, Department of Surgery, Rabindranath Tagore Medical College, Udaipur, Rajasthan. \\ ${ }^{3}$ Consultant Surgeon, Department of Surgery, Rabindranath Tagore Medical College, Udaipur, Rajasthan. \\ ${ }^{4}$ Resident, Department of Surgery, Rabindranath Tagore Medical College, Udaipur, Rajasthan. \\ ${ }_{5}^{5}$ Associate Professor and HOD, Department of Surgery, Ananta Institute of Medical Sciences, Kaliwas, Tehsil Nathdwara, Rajasthan.
}

ABSTRACT

\section{BACKGROUND}

Gastroesophageal reflux disease, alkali or acid ingestion, achalasia due to unknown aetiology are considered as main causative factors in the genesis of benign oesophageal strictures. The two types of treatment modalities are used including conservative dilatation and surgical approach according to aetiology and site of involvement. Our study attempts to understand the various aetiopathogenesis and epidemiological features of this problem and their clinical presentation; so that early detection maybe planned and various treatment modalities for achalasia cardia, peptic stricture, corrosive stricture and their results are evaluated. The aim of the study is to study various-

1. Aetiological factors of stricture oesophagus (benign).

2. Features and clinical presentation of stricture oesophagus, so that early detection maybe planned.

3. Treatment methods of management of benign oesophageal strictures.

\section{MATERIALS AND METHODS}

This is a descriptive study of dysphagia due to benign oesophageal strictures. Cases presenting in the surgical outdoor with symptoms suggestive of oesophageal stricture and admitted in different surgical and gastroenterology units were included in the study. A detailed history and examination was done in these patients. Management was done by endoscopic or manual dilatation with bougies and/or surgical operation. Surgical management consisted of Heller's cardiomyotomy or oesophagoplasty.

\section{RESULTS}

Total number of 40 patients of dysphagia due to benign oesophageal strictures were studied out of which 16 (40\%) patients were of corrosive strictures, 14 (35\%) having achalasia cardia and 10 (25\%) of peptic strictures. The male-to-female ratio was 1.35:1. The mean age was 42.62 years. Strictures due to corrosive were more common in younger age groups while $20170912 \mathrm{mthe}$ peptic stricture occurred later in life. The incidence of various symptoms were dysphagia $100 \%$, regurgitation $45 \%$, epigastric or substernal pain $35 \%$, weight loss $25 \%$ and cough in $12 \%$ cases. Patients with GERD or achalasia cardia had more dysphagia to liquid/semi-solids, while patients with corrosive ingestion (alkali/acid) had more dysphagia to solids. The most common site affected was lower third of oesophagus in $55 \%$ of cases, followed by middle third (40\%) and upper third (5\%). In present study, out of 40 patients, 25 patients were treated conservatively in form of dilatation and operative intervention was done in 15 patients. All of the patients of stricture due to GERD were treated by conservative management. Most of the patients with corrosive ingestion/unknown aetiology were treated by conservative management. All of the patients with achalasia cardia were treated by operative management. One patient out of 25 managed with conservative treatment developed complication in the form of oesophageal perforation. Out of 15 patients that were managed by operative treatment, 5 developed pulmonary complications and 5 developed wound infections. Out of 4 patients who had undergone oesophagoplasty, 2 suffered with minor anastomotic leaks. In our study, after treatment (surgery/dilatation), $85 \%$ of patients were able to swallow most of solids and liquids, $10 \%$ of patients could swallow only solids and $5 \%$ of patients could swallow only liquids or semisolids.

\section{CONCLUSION}

It can be concluded that dysphagia due to benign oesophageal stricture maybe because of post-corrosive stricture, peptic stricture, achalasia cardia, etc. Conservative treatment in the form of dilatation gives excellent results in management of dysphagia. The surgery should be offered to the patients who are otherwise fit and dilatation cannot be done due to very narrow stricture. In operative patients, results of Heller's cardiomyotomy and esophagoplasties are excellent.

\section{KEYWORDS}

Oesophageal Stricture, Corrosive Ingestion, Achalasia Cardia, Peptic Stricture.

HOW TO CITE THIS ARTICLE: Sharma KG, Sharma M, Sethi D, et al. A study on dysphagia due to benign oesophageal strictures. J. Evolution Med. Dent. Sci. 2017;6(73):5225-5231, DOI: 10.14260/Jemds/2017/1135

Financial or Other, Competing Interest: None.

Submission 04-08-2017, Peer Review 30-08-2017,

Acceptance 04-09-2017, Published 11-09-2017.

Corresponding Author:

Dr. Minaxi Sharma,

C/o. Dr. D. Sethi, \#303, Akshansh Apartment,

Keshav Nagar, Udaipur-313001,

E-mail: deepanjali.d1972@gmail.com

DOI: $10.14260 /$ jemds/2017/1135

\section{BACKGROUND}

Oesophagus is "the organ about which so little is known" and even today unfortunately, the oesophagus remains a no man's land, into whose top end, the ENT surgeons make light reconnaissance's and whose bottom end is often attacked by abdominal surgeons under cover of the diaphragm.

Physicians (from their greater elevation) still like to drop consignments of antacids down it, but these do not alter its abnormal configuration. 
But, with the advent of the oesophagoscope, the oesophagus was no longer "terra incognita." Every portion of the interior of the organ became accessible to direct examination. This advantage has enabled the discovery and definite diagnosis of many pathologic conditions, which prior to the general use of the oesophagoscope went unsuspected.[1]

Dysphagia due to benign lesions is one of the most interesting diseases due to great diversity with regards to its regional incidence worldwide.

Dysphagia due to benign oesophageal stricture is commonly the result of acute oesophagitis followed by chronic transmural oesophagitis and subsequent fibrosis. Little is known today about the factors that predispose to the benign dysphagia.

Gastroesophageal reflux disease, alkali or acid ingestion, achalasia due to unknown aetiology are considered as main causative factors in the genesis of benign lesions.

Peptic stricture due to reflux of gastric juice and stricture after corrosive ingestion are responsible for $80 \%$ of benign strictures.

Peptic stricture is a late complication of severe GERD. It is estimated to occur in $5-25 \%$ patients of oesophagitis in various studies.

Accidental corrosive lesion occurs mainly in children and small numbers in adults or teenagers. The swallowing of corrosive liquid is usually deliberate during suicidal attempts. Alkali is more frequently swallowed accidentally than acids.

Achalasia is a primary oesophageal motor disorder due to ineffective relaxation of lower oesophageal sphincter combined with loss of oesophageal peristalsis leading to impaired emptying and gradual oesophageal dilatation. It affects both sexes equally, typically presenting between the age of 20-50 years with incidence 0.5 to 1 per $1,00,000$.

Prompt diagnosis is of utmost importance, but it is often missed because of lack of awareness of early manifestation and usually present late, because of distensible nature of oesophagus compensating for partial stricture and its deep seated hidden anatomical site not accessible to routine examination.

The important symptoms are painless dysphagia, regurgitation, substernal pain, vomiting and weight loss.

A detailed history, a thorough examination, x-ray chest, Barium swallow examination and esophagoscopy are all required to know the exact level and length of stricture.

Histological confirmation should be done in suspicion of malignancy by esophagoscopic biopsy and brush cytology.

The two types of treatment modalities are used including conservative dilatation and surgical approach according to aetiology and site and extent of involvement.

Our study attempts to understand the various aetiopathogenesis and epidemiological features of this problem and their clinical presentation; so that, early detection maybe planned and various treatment modalities for achalasia cardia, peptic stricture, corrosive stricture and their results are evaluated.

\section{Aims and Objectives}

1. To study various aetiological factors of stricture oesophagus (benign).
2. To study the various features and clinical presentation of stricture oesophagus, so that early detection maybe planned.

3. To study various treatment methods of management of benign oesophageal strictures.

\section{MATERIALS AND METHODS}

The present study is a descriptive study of dysphagia due to benign oesophageal strictures. It was conducted in the Department of Surgery, Rabindranath Tagore Medical College and Maharana Bhupal Government Hospital, Udaipur, Rajasthan, India, over a period of two calendar years.

Cases presenting in the surgical outdoor with symptoms suggestive of oesophageal stricture and admitted in different surgical and gastroenterology units were included in study.

Various routine investigations and special investigations such as Barium swallow examination, esophagoscopy, bronchoscopy, indirect laryngoscopy, etc. were performed.

Two weeks were invested before any surgical intervention for administering adequate calories, intensive spirometry for pulmonary physiotherapy with a total abstinence from cigarette smoking and correction of anaemia. To ensure a caloric intake of $2000 \mathrm{kcal} /$ day central alimentation was instituted via nasogastric tube or feeding gastrostomy or jejunostomy.

Management was done by endoscopic or manual dilatation with bougies and/or surgical operation. Surgical management consisted of Heller's cardiomyotomy or oesophagoplasty.

The study comprised of 40 patients. 15 patients were selected for operative interventions. Of these, 11 were undergone Heller's myotomies, 3 coloesophagoplasties and 1 jejunoesophagoplasty.

In 25 patients, nonoperative treatment was done by endoscopic dilatation.

Various factors leading to exclusion of the patients preoperatively from operative management were poor general condition, upper one-third involvements, involvement of longer segment of oesophagus, high risk of cardiopulmonary disease and patients presenting with tracheoesophageal fistula. All these patients were excluded.

\section{DISCUSSION}

The present study was intended to evaluate the aetiological factors, clinical presentation and various treatment modalities of dysphagia due to benign oesophageal strictures.

Total number of 40 patients of dysphagia due to benign oesophageal strictures were studied, out of which, 16 (40\%) patients were of corrosive strictures, 14 (35\%) having achalasia cardia and 10 (25\%) of peptic strictures (Table 1).

In the past, peptic strictures (i.e. strictures related to reflux) of the distal oesophagus were fairly common; however, such strictures are no longer prevalent, most likely because anti-reflux therapy has become very effective and is widely used. Currently, the most common causes of benign strictures of the oesophagus are anastomotic strictures, which can develop following resection of the distal oesophagus and proximal stomach for treatment of oesophageal cancer or Barrett oesophagus and radiationinduced strictures, which frequently develop following treatment of head and neck cancer. In the latter patients, the strictures are located very proximally in the oesophagus. 
Other causes include aggressive treatments for Barrett oesophagus (such as photodynamic therapy) and nasogastric tube injury.[2]

Out of 40 patients of benign dysphagia, 23 (57.50\%) patients were male and rest $17(42.50 \%)$ were female. The male-to-female ratio was 1.35:1 (Table 1).

In the present series, most of patients were between 1545 years, i.e. $62 \%$ of patients. The youngest patient of benign dysphagia (corrosive) was 18 years and oldest was of 80 years. The mean age was 42.62 years (Table 2 ).

$69 \%$ of corrosive stricture patients were under the age of 30 years and $60 \%$ of peptic stricture patients were between 61-75 years (Table 2).

In present series, most of patients were between 15-45 years, i.e. $62 \%$ of patients. The youngest patient of benign dysphagia (corrosive) was 18 years and oldest was of 80 years. Strictures due to corrosive were more common in younger age groups while the peptic stricture occurred later in life. It may be due to more incidence of either accidental or suicidal ingestion of corrosive in younger age group with early development of stricture post ingestion. Peptic strictures develop in later age after longstanding peptic disease.

The median age of patients of dysphagia due to benign oesophageal lesions as reported by various authors was-

Median age of corrosive patients were 40 years (range 880 years) and 35.7 years (range 15-68 years) in study by Huang MH[3] (1989) and Stoica AL[4] (2004), respectively. In a study by Arevalo Silva C[5] (2006), a biphasic distribution of the patients was noted, half were children under 5 years old and the remainder were adults more than 35 years. The most frequent cause for ingestion was accidental (67\%) as opposed to attempt suicide (33\%). All cases of attempted suicide occurred in adults. Most of them reported ingestion of large amounts of caustic substance.

Median age of achalasia patients were $36.5 \pm 14.6$ years, 44 years, $44.5 \pm 14$ years (range 16-76), $41.42 \pm 18.07$ years and 40 years in Ghoshal[6] (2004), Harold KL[7] (2004), Onopriev VI[8] (2005), Boztas G[9] (2005) and Kennedy (2010)[10], respectively.

In peptic stricture, patients were of $61.1 \pm 16.3$ years and 56.1 years (range 32-82 years) in Mazzadi SA[11] (2004) and Chiu YC[12] (2004), respectively.

In the present study, 25\% of patients had history of GERD, but in Said $A^{[13]}$ (2003) study, the incidence was 77 (Table 3).

In the present study, 15 (37\%) cases had history of alkali ingestion. This was similar to that of Huang $\mathrm{MH}^{[3]}$ (1989) and Arevalo Silva C[5] (2006) who reported the incidence of 38\% and $42 \%$, respectively (Table 3 ).

In our study, acid ingestion induced strictures were $2.5 \%$ while in study by Arevalo Silva $C^{[5]}$ (2006), it was 32\% (Table 3).

Unknown aetiology and achalasia were presented in 35\% of cases in our study (Table 3).

Patti MG[14] (2005) reported $77 \%$ of achalasia cases and Arevalo Silva $\mathrm{C}^{[5]}$ (2006) reported $32 \%$ of acid ingestion, which produce benign dysphagia.

This variation in aetiological factors and age maybe due to difference in cultural and dietary habits in Indians from other countries.

Initially, sign and symptoms due to benign oesophageal stricture are minimal and nonspecific for a long duration.
Often patients do not seek medical advice until the appearance of clear-cut symptoms of dysphagia and/or regurgitation appear (Table 4).

The first and the most important symptom was progressive dysphagia, which was present in $100 \%$ of cases in our study. Unfortunately, dysphagia is not an earlier manifestation of the disease, because it manifests only after reduction of $60 \%$ of oesophageal luminal diameter occurs.

\section{Functional Grading of Dysphagia[15]}

Grade I- Eating normally.

Grade II- Requires liquids with meal.

Grade III- Able to take semisolids, but unable to take any solid food.

Grade IV- Able to take liquid only.

Grade V- Unable to take liquid, but able to swallow saliva.

Grade VI- Unable to swallow saliva.

The incidence of various symptoms were dysphagia $100 \%$, regurgitation $45 \%$, epigastric or substernal pain $35 \%$, weight loss $25 \%$ and cough in $12 \%$ cases, which are comparable with study of Mazzadi SA[11] (2004) in which dysphagia (100\%), regurgitation (40\%) and epigastric pain (30\%). Similar results were found in study of Ghoshal UC[6] (2004) with dysphagia (100\%), regurgitation (48\%), epigastric pain $(17 \%)$, weight loss $(26 \%)$ and pulmonary symptoms occurred in $18 \%$ cases.

One significant observation that emerged from this study was that $50 \%$ of patients presented with dysphagia for liquids or semi solids, $35 \%$ were only for solid and remaining $15 \%$ patients were having dysphagia for both solids and liquids. Patients with GERD or achalasia cardia had more dysphagia to liquid/semi-solids, while patients with corrosive ingestion (alkali/acid) had more dysphagia to solids (Table 5).

The relationship between symptoms and severity of injury is uncertain. Stridor and drooling were considered $100 \%$ specific for significant oesophageal injury, but no single symptom or symptom cluster can predict the degree of oesophageal damage.[16]

In present series, majority of patients, i.e. $40 \%$ presented with $<3$ months' duration followed by 30\% with 3-6 months' dysphagia, $15 \%$ with 6-9 months' dysphagia and only $5 \%$ of patients presented after 1 year of dysphagia.

Barium swallow reports were available for 30 patients. Oesophageal lesion with stricture and hold up of contrast with proximal dilatation were present in $55 \%$ patients, in $20 \%$ patients, the barium swallow was normal, which were later on proved to have the oesophageal stricture on endoscopy. Remaining 10 patients had peptic strictures and this investigation was not called for (Table 6).

In the present study, the most common site affected was lower third of oesophagus, in $55 \%$ of cases, followed by middle third (40\%) and upper third (5\%) (Table 7).

Dascalescu C[17] (2005) reported that corrosive poisons produced the lesion in $62 \%$ cases in oesophagus followed by $26 \%$ at oesophagogastric junction. The study of Mazzadi SA[11] (2004) on peptic stricture shows $97 \%$ of stricture present in lower one third of oesophagus.

Chiu YC et al (2013) reported that, of the 18 patients with oesophageal stricture alone, 6 had orifices of strictures located in the upper third of the oesophagus, 6 in the middle third and 6 in the lower third.[18] 
In our study, less than $3 \mathrm{~cm}$ length of oesophagus was involved in $47 \%$ of cases, $3-6 \mathrm{~cm}$ length was involved in $37 \%$ of cases and more than $6 \mathrm{~cm}$ was involved in only $16 \%$ of cases of benign oesophageal lesions (Table 8).

It was comparable to study of Chiu YC[12] (2004) in which length involved in $44 \%$ cases was $2.6 \pm 1 \mathrm{~cm}$. Another $44 \%$ had $5.4 \pm 3.4 \mathrm{~cm}$ and remaining $12 \%$ had more than $8 \mathrm{~cm}$.

In present study, 25 patients $(62.50 \%)$ were treated conservatively in form of dilatation and operative intervention was done in 15 patients $(37.50 \%)$ (in one patient dilatation was done and complication in the form of oesophageal perforation occurred, so operative management in the form of coloesophagoplasty was done) (Table 9). All of the patients of stricture due to GERD were treated by conservative management (Table 12). Most of the patients with corrosive ingestion/unknown aetiology were treated by conservative management. All of the patients with achalasia cardia were treated by operative management (Table 10).

The study of Chattopdhyay T.K.[19] (1989) and Poley JW[20] (2004) for corrosive stricture reported that $65 \%$ of patients were operated and $35 \%$ were treated by conservative management.

The reason for high percentage of surgical intervention in Chattopadhyay's series maybe that the study was conducted in All India Institute of Medical Sciences where most of the patients were referred from secondary and tertiary care centers for surgery.

In case of achalasia, studies of Anselmino M[21] (1997), Jani PG[22] (1998), Boztas G[9] (2005) and Gockel[23] (2005) shows treatment in $90 \%, 92 \%, 90 \%$ and $75 \%$ of patients by dilatation (conservatively), respectively.

In case of peptic stricture, the study of Bischof G[24] (1996) had $52 \%$ of patients treated by dilatation.

The disparity of treatment modality was due to variation of aetiological factors, surgeon's choice and expertise and other factors.

Majority of cases of dysphagia treated by dilatation required less than 3 dilatations in $80 \%$ cases. $15 \%$ patients required 3-6 sessions of dilatation (Table 11). It was comparable to Cheng YS[25] (2003), Boztas G[9] (2005), Ghoshal UC[6] (2004), study in which 68\% required 2.2 sessions/case and $71 \%$ required one session/case and $49 \%$ required single dilatation, respectively. Jani $\mathrm{PG}^{[22]} 1998$ reported in peptic stricture patients, average of 1.8 dilatations/case (range 1-8) were required for satisfactory response to dysphagia.

Rigorous weekly schedule of bougie dilatation and intralesional triamcinolone in combination is safe and effective in achieving significant dilatation reducing the frequency of dilatations, maintaining dilatation and improving dysphagia till one year of followup.[26]

In their study, Hsieh $\mathrm{KH}$, et al (2017) reported that IFE (interventional flexible endoscopy) with this NIV (noninvasive ventilation) support is a safe, feasible and valuable modality, which could rapidly examine and manage ES (oesophageal stenosis),[27] but Tharavej C et al (2017) reported that there were 55 patients with corrosive oesophageal strictures. Of 55 patients, 41 (75\%) had failed dilatation (38 having oesophageal replacement procedure, two continue repeated dilatation and one unfit for surgery).[28]
Failure of dilatation was defined as one of the followingcomplete luminal stenosis, inability to perform safe dilatation, perforation and inability to maintain adequate luminal patency. Surgery or repeated dilatation was indicated in failed dilatations.[28]

In our study, out of 40 patients, 15 (37.50\%) were treated by operative management. Out of 15 patients, 11 patients were selected for Heller's cardiomyotomy, remaining 4 patients were operated by oesophagoplasty. Out of 4 patients selected for oesophagoplasty, 3 were operated by retrosternal route and 1 through transhiatal route (Table 12).

One of patients in present series had caustic ingestion and developed TOF, but was treated at other centre for TOF and later the patient developed stricture in oesophagus and she was treated by coloesophagoplasty.

All of the patients of achalasia were treated by Heller's myotomy (Table 12).

Present study is comparable in case of achalasia with Mattioli S[29] (1996) who had done long oesophagogastric myotomy (abdominal) in 62\% cases. In Harold KL[7] (2004) series, $91 \%$ patients underwent myotomy with Toupet fundoplication (laparoscopic). In his series of 176 patients by Liu JF[30] (2004), all patients underwent modified Heller's myotomy with $84.5 \%$ having good or excellent relief of symptoms after 14 years of follow-up.

In their study, Oelschlanger BK[31] (2003), Patti MG[14] (2005) and Gockel I[23] (2005) various type of myotomy were performed only in $52 \%, 58 \%$ and $35 \%$ of patients.

In all the 4 patients of corrosive stricture that were managed by operative procedures, oesophagoplasty was performed, out of which 3 patients were treated by coloesophagoplasty (left colon) and 1 patient by jejunoesophagoplasty (Table 12).

In case of corrosive stricture, Dascalesecu C[17] (2005) reported that $41 \%$ of patients had esophagoplasties with left colon, $27 \%$ of patients with ascending colon, $19 \%$ of patients with transhiatal resections with cervical oesophagogastric anastomosis and remaining $11 \%$ had transverse colon with splenic flexures.

Aghaji MA[32] (1993) studied that in 90\% cases, left colon was used for oesophageal replacement.

Popvici Z[33] (1977) reported that $25 \%$ of patients of post caustic stenosis were operated for retrosternal transposition of colonic segment.

One patient out of 25 managed with conservative treatment developed complication in the form of oesophageal perforation (Table 13).

The perforation of oesophagus was initially managed conservatively by gastrostomy and intercostal chest tube drainage and later coloesophagoplasty was done.

Out of 15 patients that were managed by operative treatment, 5 developed pulmonary complications and 5 developed wound infections (Table 13).

Pulmonary complications were tackled by intensive chest physiotherapy. Wound infections were resolved by use of antibiotic according to culture sensitivity and good aseptic precaution.

Out of 4 patients who had undergone oesophagoplasty, 2 suffered with anastomotic leaks (Table 13).

Anastomotic leaks were minor and spontaneously subsided within a week. 
Tharavej C et al (2017) reported that, 8 out of 55 patients (14.5\%) had perforations. ${ }^{[28]}$

In their study, Hsieh $\mathrm{KH}$ et al (2017) reported that 1 oesophageal perforation developed after balloon dilatation $(1 / 63) .[27]$

Aghaji MA ${ }^{[32]}$ (1993) reported that major postoperative complications were proximal anastomotic leaks $49 \%$, wound sepsis $25 \%$, pulmonary complications $27 \%$ and colon graft necrosis $4 \%$ of cases.

In our study, after treatment (surgery/dilatation), $85 \%$ of patients were able to swallow most of solids and liquids, $10 \%$ of patients could swallow only solids and $5 \%$ of patients could swallow only liquids or semisolids (Table 14).

In our study, $60 \%$ of patients were discharged within 3 days of admission (which were treated conservatively), 90\% discharged within 9 days of admission. Only 10\% patients were discharged after 9 or more days, which suffered from wound infections or other operative complications.

\section{CONCLUSION}

It can be concluded that dysphagia due to benign oesophageal stricture maybe because of post-corrosive stricture, peptic stricture, achalasia cardia, etc. Conservative treatment in the form of dilatation gives excellent results in management of dysphagia. The surgery should be offered to the patients who are otherwise fit and dilatation cannot be done due to very narrow stricture. In operative patients, results of Heller's cardiomyotomy and esophagoplasties are excellent.

\begin{tabular}{|c|c|c|c|c|c|}
\hline \multirow{2}{*}{$\begin{array}{l}\text { Sl. } \\
\text { No. }\end{array}$} & \multirow{2}{*}{ Lesion } & \multicolumn{3}{|c|}{ No. of Cases } & \multirow{2}{*}{$\%$} \\
\hline & & Male & Female & Total & \\
\hline 1. & $\begin{array}{c}\text { Achalasia } \\
\text { cardia/unknown } \\
\text { aetiology }\end{array}$ & 9 & 5 & 14 & $35 \%$ \\
\hline 2. & Corrosive stricture & 9 & 7 & 16 & $40 \%$ \\
\hline \multirow[t]{2}{*}{3.} & Peptic stricture & 5 & 5 & 10 & $25 \%$ \\
\hline & Total & 23 & 17 & 40 & $100 \%$ \\
\hline \multicolumn{6}{|c|}{$\begin{array}{c}\text { Table 1. Gender Wise Distribution of } \\
\text { Oesophageal Stricture Cases }\end{array}$} \\
\hline
\end{tabular}

\begin{tabular}{|c|c|c|c|c|c|}
\hline \multirow{2}{*}{ Age } & $\begin{array}{c}\text { Achalasia } \\
\text { Cardia/ } \\
\text { Unknown } \\
\text { Aetiology }\end{array}$ & $\begin{array}{l}\text { Corrosive } \\
\text { Stricture }\end{array}$ & $\begin{array}{c}\text { Peptic } \\
\text { Stricture }\end{array}$ & \multicolumn{2}{|c|}{ Total } \\
\cline { 2 - 6 } No. of Cases & $\begin{array}{c}\text { No. of } \\
\text { Cases }\end{array}$ & $\begin{array}{c}\text { No. of } \\
\text { Cases }\end{array}$ & $\begin{array}{c}\text { No. of } \\
\text { Cases }\end{array}$ & $\%$ \\
\hline $15-30$ & 4 & 11 & 1 & 16 & $40 \%$ \\
\hline $31-45$ & 3 & 4 & 2 & 9 & $22 \%$ \\
\hline $46-60$ & 2 & - & - & 2 & $5 \%$ \\
\hline $61-75$ & 3 & 1 & 6 & 10 & $25 \%$ \\
\hline $76-90$ & 2 & - & 1 & 3 & $8 \%$ \\
\hline \multicolumn{7}{|c|}{} & 14 & 16 & 10 & $\mathbf{4 0}$ & $\mathbf{1 0 0} \%$ \\
\hline \multicolumn{7}{|c|}{$\begin{array}{c}\text { Table 2. Age Wise Distribution of } \\
\text { Oesophageal Stricture Cases }\end{array}$} \\
\hline
\end{tabular}

\begin{tabular}{|c|c|c|c|}
\hline $\begin{array}{l}\text { Sl. } \\
\text { No. }\end{array}$ & Aetiological Factors & $\begin{array}{l}\text { No. of } \\
\text { Cases }\end{array}$ & Percentage \\
\hline 1. & GERD/Acid peptic disease & 10 & $25 \%$ \\
\hline 2. & Alkali ingestion & 15 & $37.50 \%$ \\
\hline 3. & Acid ingestion & 1 & $2.50 \%$ \\
\hline 4. & Achalasia cardia & 10 & $25 \%$ \\
\hline 5. & Unknown aetiology & 4 & $10 \%$ \\
\hline & Total & 40 & $100 \%$ \\
\hline \multicolumn{4}{|c|}{$\begin{array}{c}\text { Table 3. Aetiological Factor Wise } \\
\text { Distribution of Oesophageal Stricture }\end{array}$} \\
\hline
\end{tabular}

\begin{tabular}{|c|c|c|c|}
\hline $\begin{array}{r}\text { Sl. } \\
\text { No. }\end{array}$ & Symptoms & No. of Cases & Percentage \\
\hline 1. & Dysphagia & 40 & $100 \%$ \\
\hline 2. & Regurgitation/vomiting & 18 & $45 \%$ \\
\hline 3. & Substernal/epigastric pain & 14 & $35 \%$ \\
\hline 4. & Weight loss & 10 & $25 \%$ \\
\hline 5. & Cough & 5 & $12 \%$ \\
\hline \multicolumn{3}{|c|}{ Table 4. Symptoms of Oesophageal Stricture } \\
\hline
\end{tabular}

\begin{tabular}{|c|c|c|c|c|}
\hline \multirow{2}{*}{$\begin{array}{c}\text { Sl. } \\
\text { No. }\end{array}$} & Aetiology & \multicolumn{3}{|c|}{ Type of Dysphagia } \\
\cline { 3 - 5 } & & Solid & $\begin{array}{c}\text { Liquid/Semi- } \\
\text { Solid }\end{array}$ & Total \\
\hline 1. & GERD & 2 & 8 & - \\
\hline 2. & Corrosives (alkali/acid) & 10 & - & $\mathbf{6}$ \\
\hline 3. & Achalasia/unknown & 2 & 12 & - \\
\hline & Total & $\mathbf{1 4}$ & $\mathbf{2 0}$ & $\mathbf{6}$ \\
\hline & &
\end{tabular}

Table 5. Type of Dysphagia

\begin{tabular}{|c|c|c|c|}
\hline $\begin{array}{c}\text { Sl. } \\
\text { No. }\end{array}$ & $\begin{array}{c}\text { Barium Swallow } \\
\text { Finding }\end{array}$ & $\begin{array}{c}\text { No. of } \\
\text { Cases }\end{array}$ & Percentage \\
\hline 1. & Oesophageal stricture & 12 & $30 \%$ \\
\hline 2. & Hold up with dilatation & 10 & $25 \%$ \\
\hline 3. & Normal & 8 & $20 \%$ \\
\hline 4. & Not available & 10 & $25 \%$ \\
\hline \multicolumn{3}{|c|}{ Table 6. Various Radiological Sign } \\
As Seen On Barium Oesophagogram \\
\hline
\end{tabular}

\begin{tabular}{|c|c|c|c|}
\hline Sl. No. & Site & $\begin{array}{c}\text { No. of } \\
\text { Cases }\end{array}$ & Percentage \\
\hline 1. & Upper one third $(15-23 \mathrm{~cm})$ & 2 & $5 \%$ \\
\hline 2. & Middle one third $(24-31 \mathrm{~cm})$ & 16 & $40 \%$ \\
\hline 3. & Lower one third $(32-40 \mathrm{~cm})$ & 22 & $55 \%$ \\
\hline \multicolumn{3}{|c|}{ Table 7. Level of Oesophageal Stricture } \\
According to Esophagoscopy \\
\hline
\end{tabular}

\begin{tabular}{|c|c|c|c|}
\hline Sl. No. & Extent of Stricture & No. of Cases & Percentage \\
\hline 1. & $0-3 \mathrm{~cm}$ & 19 & $47 \%$ \\
\hline 2. & $3-6 \mathrm{~cm}$ & 15 & $37 \%$ \\
\hline 3. & $6-9 \mathrm{~cm}$ & 5 & $13 \%$ \\
\hline 4. & $>9 \mathrm{~cm}$ & 1 & $3 \%$ \\
\hline \multicolumn{4}{|c|}{ Table 8. Extent of Stricture as Seen on Esophagoscopy } \\
\hline
\end{tabular}

\begin{tabular}{|c|c|c|c|}
\hline Sl. No. & Treatment & No. of Cases & Percentage \\
\hline 1. & Conservative & 25 & $62.50 \%$ \\
\hline 2. & Operative & 14 & $35 \%$ \\
\hline 3. & Both & 1 & $2.50 \%$ \\
\hline \multicolumn{3}{|c|}{ Table 9. Management of Dysphagia } \\
\hline
\end{tabular}

\begin{tabular}{|c|c|c|c|c|}
\hline Sl. No. & Aetiology & $\begin{array}{c}\text { No. of } \\
\text { Patients }\end{array}$ & Conservative & Operative \\
\hline 1. & GERD & 10 & 10 & - \\
\hline 2. & $\begin{array}{l}\text { Corrosive } \\
\text { ingestion }\end{array}$ & 16 & 12 & 4 \\
\hline 3. & Achalasia & 10 & - & 10 \\
\hline 4. & Unknown & 4 & 3 & 1 \\
\hline & Total & 40 & 25 & 15 \\
\hline \multicolumn{5}{|c|}{$\begin{array}{l}\text { Table 10. Distribution of Cases } \\
\text { ccording to Type of Managemen }\end{array}$} \\
\hline
\end{tabular}




\begin{tabular}{|c|c|c|c|}
\hline Sl. No. & $\begin{array}{c}\text { No. of Dilatations } \\
\text { Per Patient }\end{array}$ & No. of Cases & Percentage \\
\hline 1. & $0-3$ & 20 & $80 \%$ \\
\hline 2. & $3-6$ & 4 & $15 \%$ \\
\hline 3. & $>6$ & 1 & $4 \%$ \\
\hline \multicolumn{3}{|c|}{ Table 11. Frequency of Dilatations } \\
\hline
\end{tabular}

\begin{tabular}{|c|c|c|c|c|}
\hline $\begin{array}{c}\text { Sl. } \\
\text { No. }\end{array}$ & Disease & $\begin{array}{c}\text { No. of } \\
\text { Cases }\end{array}$ & $\begin{array}{c}\text { No. of Cases } \\
\text { Operated }\end{array}$ & $\begin{array}{c}\text { Type of } \\
\text { Operation }\end{array}$ \\
\hline 1. & GERD/peptic & 10 & 0 & - \\
\hline 2. & Achalasia & 10 & 10 & Heller's \\
\hline 3. & Corrosive & 16 & 4 (alkali) & Oesophagoplasty \\
\hline 4. & Unknown & 4 & 1 & Heller's \\
\hline \multicolumn{6}{|c|}{ Table 12. Type of Operative Treatment } \\
\hline
\end{tabular}

\begin{tabular}{|c|c|c|c|c|}
\hline $\begin{array}{c}\text { Sl. } \\
\text { No. }\end{array}$ & Complications & No. of Patients & $\begin{array}{c}\text { No. of } \\
\text { Complication }\end{array}$ & $\%$ \\
\hline 1. & $\begin{array}{c}\text { Perforation } \\
\text { during } \\
\text { dilatation }\end{array}$ & 25 (conservative) & 1 & $4 \%$ \\
\hline 2. & $\begin{array}{c}\text { Anastomotic } \\
\text { leaks }\end{array}$ & $\begin{array}{c}4 \\
\text { (oesophagoplasty) }\end{array}$ & 2 & $50 \%$ \\
\hline 3. & $\begin{array}{c}\text { Pulmonary } \\
\text { complications }\end{array}$ & 15 (operative) & 5 & $33 \%$ \\
\hline 4. & $\begin{array}{c}\text { Wound } \\
\text { infection }\end{array}$ & 15 (operative) & 5 & $33 \%$ \\
\hline \multicolumn{5}{|c|}{$\begin{array}{c}\text { Table 13. Complications of Management } \\
\text { of Benign Oesophageal Stricture }\end{array}$} \\
\hline
\end{tabular}

\begin{tabular}{|c|c|c|c|}
\hline Sl. No. & Response to Treatment & $\begin{array}{c}\text { No. of } \\
\text { Cases }\end{array}$ & Percentage \\
\hline 1. & $\begin{array}{c}\text { Able to swallow most of solids } \\
\text { and liquids }\end{array}$ & 34 & $85 \%$ \\
\hline 2. & Able to swallow only solids & 4 & $10 \%$ \\
\hline 3. & $\begin{array}{c}\text { Able to swallow only semi-solids } \\
\text { or liquids }\end{array}$ & 2 & $5 \%$ \\
\hline \multicolumn{3}{|c|}{$\begin{array}{c}\text { Table 14. Response to Treatment of } \\
\text { Dysphagia in Oesophageal Stricture Patients }\end{array}$} \\
\hline
\end{tabular}

\section{Abbreviations}

GERD - Gastroesophageal reflux disease.

TOF - Tracheoesophageal fistula

IFE - Interventional flexible endoscopy

ES - Oesophageal stricture

\section{REFERENCES}

[1] Moyer JS. Esophagoscopic study of esophageal varices: report of two cases of esophageal varices persisting after splenectomy. Arch Otolaryngol 1929;10(4): 409-19.

[2] Baron TH. Management of benign esophageal strictures. Gastroenterol Hepatol (N Y) 2011;7(1): 46-9.

[3] Huang MH, Sung CY, Hsu HK, et al. Reconstruction of the esophagus with the left colon. Ann Thorac Surg 1989;48(5):660-4.

[4] Stoica AL, Bordos D, Miculit F, et al. Benign esophageal strictures-outcomes of coloesophagoplasty in surgical clinic ii timişoara. Chirurgia (Bucur) 2004;99(6): 507-13.
[5] Arévalo-Silva C, Eliashar R, Wohlgelernter J, et al. Ingestion of caustic substances: a 15-year experience. Laryngoscope 2006;116(8):1422-6.

[6] Ghoshal UC, Kumar S, Saraswat VA, et al. Long-term follow-up after pneumatic dilation for achalasia cardia: factors associated with treatment failure and recurrence. Am J Gastroenterol 2004;99(12):2304-10.

[7] Harold KL, Matthews BD, Kercher KW, et al. Surgical treatment of achalasia in the 21st century. South Med J 2004;97(1):7-10.

[8] Onopriev VI, Durleshter VM, Ryabchun VV. Comparative pre- and postoperative results analysis of functional state of the esophagus assessment in patients with various stages of achalasia. Eur J Cardiothorac Surg 2005;28(1):1-6.

[9] Boztas G, Mungan Z, Ozdil S, et al. Pneumatic balloon dilatation in primary achalasia: the long-term followup results. Hepatogastroenterology 2005;52(62): 475-80.

[10] Kennedy R, Menezes C, Ahmad J, et al. Laparoscopic cardiomyotomy for achalasia: a single unit study. Ulster Med J 2010;79(1):16-9.

[11] Mazzadi SA, García AO, Salis GB, et al. Peptic esophageal stricture: a report from Argentina. Dis Esophagus 2004;17(1):63-6.

[12] Chiu YC, Hsu CC, Chiu KW, et al. Factors influencing clinical applications of endoscopic balloon dilation for benign esophageal strictures. Endoscopy 2004;36(7):595-600.

[13] Said A, Brust DJ, Gaumnitz EA, et al. Predictors of early recurrence of benign esophageal strictures. Am J Gastroenterol 2003;98(6):1252-6.

[14] Patti MG, Gorodner MV, Galvani C, et al. Spectrum of esophageal motility disorders: implications for diagnosis and treatment. Arch Surg 2005; 140(5):442-8.

[15] Coia LR, Myerson RJ, Tepper JE. Late effects of radiation therapy on the gastrointestinal tract. Int $\mathrm{J}$ Radiat Oncol Biol Phys 1995;31(5):1213-36.

[16] Contini S, Scarpignato C. Caustic injury of the upper gastrointestinal tract: a comprehensive review. World J Gastroenterol 2013;19(25):3918-30.

[17] Dăscălescu C, Bulat C, Dănilă R, et al. Tailored surgical treatment for post-caustics stenosis of the upper digestive tract with complicated lesions. Clinical experience at our department in the last ten years. Rev Med Chir Soc Med Nat Iasi 2005;109(1):77-81.

[18] Yi-Chun C, Chih-Ming L, Tam W, et al. The effects of endoscopic-guided balloon dilations in esophageal and gastric strictures caused by corrosive injuries. BMC Gastroenterol 2013;13:99.

[19] Chattopadhyay TK, Kapoor VK, Gupta S. The management of extensive corrosive esophageal strictures: do not dilate and procrastinate. Jpn J Surg 1989;19(2):171-6.

[20] Poley JW, Steyerberg EW, Kuipers EJ, et al. Ingestion of acid and alkaline agents: outcome and prognostic value of early upper endoscopy. Gastrointest Endosc 2004;60(3):372-7.

[21] Anselmino M, Perdikis G, Hinder RA, et al. Heller myotomy is superior to dilatation for the treatment of early achalasia. Arch Surg 1997;132(3):233-40. 
[22] Jani PG, Mburugu PG. Outpatient experience with oesophageal endoscopic dilation. East Afr Med J 1998;75(7):422-4.

[23] Gockel I, Junginger T, Eckardt VF. Effects of pneumatic dilation and myotomy on esophageal function and morphology in patients with achalasia. Am Surg 2005;71(2):128-31.

[24] Bischof G, Feil W, Riegler M, et al. Peptic esophageal stricture: is surgery still necessary? Wien Klin Wochenschr 1996;108(9):267-71.

[25] Ying-Sheng C, Ming-Hua L, Wei-Xiong C, et al. Selection and evaluation of three interventional procedures for achalasia based on long-term follow-up. World J Gastroenterol 2003;9(10):2370-3.

[26] Nijhawan S, Udawat HP, Nagar P. Aggressive bougie dilatation and intralesional steroids is effective in refractory benign esophageal strictures secondary to corrosive ingestion. Dis Esophagus 2016;29(8): 1027-31.

[27] Hsieh KH, Soong WJ, Jeng MJ, et al. Flexible endoscopic diagnosis and treatment of esophageal stenosis in children with noninvasive ventilation support. Pediatr Neonatol 2017:S1875-9572(17)30288-7.
[28] Tharavej C, Pungpapong SU, Chanswangphuvana P. Outcome of dilatation and predictors of failed dilatation in patients with acid-induced corrosive esophageal strictures. Surg Endosc 2017.

[29] Mattioli S, Di Simone MP, Bassi F, et al. Surgery for esophageal achalasia. Long-term results with three different techniques. Hepatogastroenterology 1996;43(9):492-500.

[30] Jun-Feng L, Zhang J, Zi-Qiang T, et al. Long-term outcome of esophageal myotomy for achalasia. World J Gastroenterol 2004;10(2):287-91.

[31] Oelschlager BK, Chang L, Pellegrini CA. Improved outcome after extended gastric myotomy for achalasia. Arch Surg 2003;138(5):490-5; discussion 495-7.

[32] Aghaji MA, Chukwu CO. Oesophageal replacement in adult Nigerians with corrosive oesophageal strictures. Int Surg 1993;78(3):189-92.

[33] Popovici Z. Special aspects of coloesophagoplasty in post-caustic esophageal stenosis for corrosive stricture of the esophagus. J Chir (Paris) 1977;113(3):269-78. 